\title{
UTILIZATION OF THE PUPPET STAGE AS A METHOD OF CONTEXTUAL EVANGELISM TO SUNDAY SCHOOL CHILDREN AGED 5-10 YEARS
}

Agnes Alicia $^{1)}$ Ayu Rotama Silitonga ${ }^{2)}$ Agustina Bela $^{3)}$ Ayang Emiyati ${ }^{4)}$

1) Semarang- Sekolah Tinggi Teologi Simpson

Email: agnesaliciawulandari25@gmail.com

2) Semarang-Sekolah Tinggi Teologi Simpson

Email: ayurotama@gmail.com

3) Semarang-Sekolah Tinggi Teologi Simpson

Email: agustinabella754a@gmail.com

4) Semarang-Sekolah Tinggi Teologi Simpson

Email: ayangemiyati987@gmail.com

\begin{abstract}
Children's ministry is very motivating for the church and child servants because it affects the growth of the child's faith. One of them is the ministry of evangelism. Evangelism is the message of salvation and judgment in Christ Jesus. Children aged 5 - 10 years do not usually understand and interpret themselves as "Christians" because they only follow what their parents do and do. = 'So it is necessary to teach through evangelism to these children. The question is how does a minister convey the "gospel" message to children so that it can be understood easily and what are the results of the ministry? This paper has two purposes. First, the servant understands the method or way of a servant to convey the "gospel" message simply. Second, so that children better understand the true meaning of the Bible. The research method used is qualitative by interviewing sources to examine and understand the attitudes, views, feelings and behavior of an individual or group of people and literature research to support this writing.
\end{abstract}

Keywords: Evangelism, Contextual, Children, Puppet Stage

\section{INTRODUCTION}

Evangelism comes from the word "Gospel", Greek "Evangelion" which means good news or the delivery of good news. According to the Indonesian dictionary, it means "process" or "how to evangelize". According to the English - Indonesian dictionary "Evanjelism" means the spread of the Bible. ${ }^{1}$ So it can be concluded that evangelism is preaching the good news about Jesus Christ from the salvation and judgment that humans feel as believers. Timotius Hardono said in his book that there were 4 main points of news that were conveyed. First, the Death and Resurrection of Jesus. Second, atonement for sins. Third, 
how to receive and believe in Jesus Christ.

The fourth is the result of that Evangelism, which is gaining souls. ${ }^{2}$

The good news that is conveyed is not only for people who do not know Jesus personally or those who do not believe. The sharing of the good news or evangelism is also needed for believers to be more confident in their faith in Jesus Christ, especially for children who are still learning about the Word of God or Sunday school children. Children are a unique person, Antony \& Elizabeth Capon in their work, The Chruch And The Child (1967), it is quite right to state that "Children are mature persons in their own views. This means that children have the potential to understand, understand, but according to their level of development. ${ }^{3}$ So, children need a simple explanation according to the child's age. In the age of 5-10 years, children are learning to capture new things in themselves through their families, schools or the environment around them. At this time it is very important to teach or instill faith in these children. According to Santosa, in his journal, Childhood life determines life in

\footnotetext{
${ }^{2}$ Op cit

${ }^{3}$ Rida Gultom, Dame Taruli, and Genti Turnip, Pendidikan Agama Kristen Kepada Anak Anak (Medan: MITRA, n.d.), 13.

${ }^{4}$ Guntur Firman Aprianto, "Implementasi Penginjilan Dan Pemuridan Dalam Pengembangan Karakter Jujur Anak 9 - 10 Tahun" 2 No. 2 (January 2020).
}

adulthood. Therefore, it is very appropriate to introduce Christ to children as early as possible and the delivery is adjusted to the child's level of development. ${ }^{4}$

Tabitha Kartika in her journal discusses the thoughts of people who are sometimes pessimistic about children. This can cause children to be underappreciated, especially when we see that children, as sinful humans, are not yet able to express their repentance. ${ }^{5}$ Therefore, servants need to provide understanding and guidance in conveying the gospel to children. James Dobson in his book illustrates a child like a gosling that hatches and comes out then gets attached to the first thing it sees which is its mother. This gosling will follow wherever its mother goes and from then on, it will follow wherever the closest object moves, whether living or dead as a substitute for its parent. In other words, there is a brief and important period in the life of a gosling and it is only during this time that he may learn a narrative lesson. ${ }^{6}$ The same is the case with children who also follow what their parents do / follow their parents' habits from childhood. Children also need a period in

\footnotetext{
${ }^{5}$ Tabitha Kartika, "Belajar Dari Sejarah Gereja Pendidikan Kristiani Untuk Anak Melalui Sekolah Minggu” 31, no. 1 (April 2007).

${ }^{6}$ James Dobson, Masalah Membesarkan Anak (Bandung: Kalam Hidup, 2005), 41.
} 
which they understand important and influential clues in their lives.

When dealing with children, you must position yourself like children. The ministry of evangelizing must be contextual. The term Context is used in different meanings. Context in a general sense refers to the situations and conditions of the world faced by the people around them. If studied in theology, contextualization means combining the Bible's mandate with the situations and conditions faced. It is the same as preaching the gospel to children, the evangelist must convey it in accordance with the existing context. One way to teach children is through a puppet stage. Cipto L. Simanjuntak in his article said that "The puppet stage is one of the media used to convey messages in drama, using dolls. The difference between a play and a puppet stage only depends on the type of doll. The puppet stage comes from 'putrika, puhitrika, puttali' in Indian Sanskrit which means girl according to Pishel. In Latin and Greek too, dolls come from the word 'girl or boy' ", ?

The puppet stage can be a good medium or tool to convey God's word in the form of a story, because the children are

\footnotetext{
${ }^{7}$ Cipto Simanjuntak, "Teori Dan Praktek Panggung Boneka," last modified 2018, http://simanjuntakcipto.blogspot.com/2018/01/teoridan-praktek-panggung-boneka.html) 28 Januari 2018.
}

very close to the doll's name and will be more interested in this tool than just telling stories without the media.

\section{RESEARCH METHOD}

To obtain information in this writing, the authors use qualitative methods. Dr. Lexy J. Moleong said that qualitative methods are research that uses open interviews to examine and understand the attitudes, views, feelings and behavior of an individual or a group of people. ${ }^{8}$ The author also uses the literature study method by making observations on books and journals to support writing. The author will also go down to the research location, namely assessing the response of Sunday school children aged 5-10 years and child servants who have been involved to get the appropriate information.

\section{RESULTS AND DISCUSSION}

Discussion on the use of the puppet stage as a method of contextual evangelism to Sunday school children aged 5-10 years

Contextual evangelism to Sunday school children aged 5-10 years was carried out by the author in 2017 . The

\footnotetext{
${ }^{8}$ Lexy Moleong, Metodologi Penelitian Kualitatif (Bandung: PT REMAJA ROSDAKARYA, 2018), 5 .
} 
writer saw that the children, before hearing the story, had interested and curious when looking at the puppet stage equipment, where there is a stage made of a series of small water pipes and decorated with colored cloth and there are small to large size dolls. It can be concluded again that the puppet stage turned out to be an attractive medium for evangelistic ministry. James Dobson again says in his book that the fifth year in a child's life is an important time and the child is at a crossroads which means whether the child will accept a spiritual concept / thing as a concept or the child will reject it. This is where the role of parents and Sunday school teachers to teach or share the gospel to children. ${ }^{9}$ The author will discuss the methods used when serving through the puppet stage.

\section{Telling Creative Stories to Attract}

\section{Attention}

Delivering safety to children is very important because children can remember what the teacher taught, when the child is young. In this section, creative delivery is very good for children so that children are interested and do not get bored easily to hear

\footnotetext{
${ }^{9}$ Dobson, Masalah Membesarkan Anak, 41.

${ }^{10}$ Linus Sumule, "Implementasi Strategi Kreatifitas Dan Bervariasi Dalam Semangat
}

the news of salvation. According to Linus Sumule, in his journal, he explained that implementing the creative strategy of a Sunday school teacher is not only talking in front of the children, but Sunday school teachers must also think about how to make children not easily bored and bored in listening to God's Word that is delivered. In an effort to implement this strategy a Sunday school teacher must understand the child's development and of course also understand the attitude of the children being taught. ${ }^{10}$

The creative Sunday school teacher is a very creative mindset venture that seeks to appeal to every Sunday school child. Creative teachers are those who have been tested when the teacher faces difficulties in teaching Sunday school children. (Yanti Bua) An example that can be done in creatively telling stories is to invite children to sing, dance, and play games that build children's enthusiasm for doing the activities concerned. Another example is when starting a story, you can use a funny voice like a child in general but the doll is not visible, so the children will be curious about where the sound came from. When the children have focused their attention on

Sekolah Minggu Kelas Remaja Dalam Menggerakan Firman Tuhan" (2020), https//osf.io/x8cwh. 
the voice, a doll appears and continues with the story about the gospel to be conveyed.

\section{Delivery Using Simple Language}

Delivery using simple language to children is very necessary in telling a story, especially in telling the truth of God's Word. ${ }^{11}$ The author says about the simple meaning of language, namely the vocabulary used is vocabulary that is easily understood by children, the structure is not complicated, the sentences are short and simple.

In this case, a Sunday school teacher must understand how to convey a story in the simplest possible language. Especially for these Sunday school children aged 5-10 years. Children this age lack self-confidence so they have a shy nature and on the other hand, children this age. According to Eka Sapti Cahyaningrum in his journal, "they have the nature of imitating what the people around them do". ${ }^{12}$ So they really need good and correct direction, education, and guidance so that children have the correct understanding and understanding and knowledge of the stories we tell. The puppet stage as it is known is a medium that has succeeded in attracting children's attention,

\footnotetext{
n.d.

${ }^{11}$ Ernawati Waridah, Buku Pintar UASBN,

12 Eka Sapti Cahyaningrum, "Pengembangan Nilai Nilai Karakter Anak Usia Dini Melalui Pembiasaan
}

it is certain that when using language puppets it must be simple or in accordance with the innocence of children playing with dolls. It is better not to use formal words in telling stories to children. Again, colloquialism is the best choice for communicating with children of this age.

\section{Sharing Using Interesting Stories}

Sharing the news of safety to children is very important. Riniwati in her journal states that in Christianity, salvation is the main thing in human life. Likewise with other religions. They do charity, do good, do goodness and so on to get salvation. There are rich people who already feel comfortable in life, or there are people who are very smart, famous and admired by many people but they are not necessarily saved, meaning it is all useless outside of Kritsus. To be apart from Christ means to have eternal death. ${ }^{13}$ So, it can be seen that it is important to convey the message of salvation / gospel contextually to children. The first method that needs attention is how the evangelistic teacher / minister delivers the news in an interesting way. The message of Salvation can be composed using children's stories but still based on the

Dan Keteladanan” 6, no. 2 (2017): 203.

${ }^{13}$ Riniwati, "Pembinaan Guru Sekolah Minggu Untuk Mengajarkan Konsep Keselamatan Pada Anak" 4, no. 2 (July 2020). 
words of God that are learned. Of course, the child servant must understand salvation and have faith in him. The child servant must understand the meaning of the gospel in himself then convey it to the children.

Child servants can use children's stories that are currently famous. For example, using the name of a cartoon they usually watch but with a different story and certainly in accordance with the theme of evangelism. Media The puppet stage is very helpful for the servants to tell stories and get children's attention because dolls are something that children are close to and like. Servants can also use stories that are in the Bible. Like the story about Zacchaeus who was short, sinned but he was forgiven by God because of His love. Lawrence says in his book that "Children are not just thoughts. Children should be taught with this setting and assumptions: First, the Bible is God's revelation of reality which means truth truth can and must be experienced. Second, children are personal. As humans, children can respond to faith and can experience realities that have not been revealed in the word. Third, therefore, children can be taught the Word of God / Bible. Given the reality that is revealed in the Bible and experienced by children as long as there is a

${ }^{14}$ Lawrence Richard, Pelayanan Kepada Anak - Anak (Bandung: Kalam Hidup, 2007), 89. general basis, the barriers to children's cognitive limitations will no longer be insurmountable. ${ }^{14}$ " Evangelical ministers can find a way to convey the word of God in a meaningful way, by returning to it using a puppet stage that attracts children's attention and stories that impress and understand the children.

\section{Delivery by Involving Children in Storytelling}

Evangelism to Sunday school children is also expected to influence the spiritual growth of children. Paul D. Meier, et al in his book explains that there are eight stages of spiritual development before the experience of new birth. First, a person is aware of the existence of Almighty God but does not understand the Bible. Second, through the gospel comes regret and awareness of the message of Christ. Third, the initial awareness arises and includes the basics of the message. Fourth, the implications of the gospel are beginning to be understood. Fifth, followed by a positive attitude towards Christ and the gospel. Sixth, realizing there was a problem - not surviving. Seventh, the decision to accept or reject. Eighth, includes repentance and faith in Christ. ${ }^{15}$ From the description above, it can be understood that to study the Bible

\footnotetext{
${ }^{15}$ Paul Meier et al., Pengantar Psikologi Dan Konseling Kristen (Jogjakarta: ANDI, n.d.), 109.
} 
requires stages in order to understand and finally accept the gospel well. Here, the minister of evangelism takes part in making the children understand about the gospel that will be preached through the puppet stage.

Servants can invite or involve children in telling stories. For example, the waiter conducts question and answer chat directly to the child, of course, using the existing puppet stage media. It is in the question and answer chat that the waiter can find out whether the child understands or not what is being said. When the servant engages the child, the child will be more interested and there will be curiosity about the story being told. Of course, keep in mind that the original purpose of storytelling is to convey the gospel to children. Pattinama in his article said that Teaching means giving correct teaching to produce change and seeing the Word of God. ${ }^{16}$

\section{Implications}

The author hopes that this research can help child servants who serve in Sunday Schools to implement evangelism to children from an early age using the puppet stage. Children's life greatly affects their growth when they grow up, because children will remember things they learned as a child. By

${ }^{16}$ YA Pattinama, "Dasar Alkitabiah Dalam evangelizing children aged 5 - 10 years through a puppet stage, of course by telling stories, it is hoped that children will understand the meaning of the gospel in their life or the meaning of being followers of Christ so that later children will not waver in their own faith. With this research, child servants / Sunday school teachers can apply it well and be more enthusiastic to preach the gospel to children without fear, in the sense that the child is afraid of not understanding and accepting the teaching given.

\section{Recommendations for Further Research}

The author recommends that further research be research on children's responses after listening to the gospel teaching. Because in this study it only refers to the child servant method of conveying the gospel through a puppet stage without directly examining it.

\section{CONCLUSION}

In the Bible, Matthew 28: 19-20 says that Christians or followers of Jesus are commanded to preach the gospel to anyone. In the sense that children are also included

Mengajar Anak," artikel, https//files.osf.io. 
in the scope. In the Bible it is also emphasized that children are very valuable and are heirs of the Kingdom of God, so that the Sunday school servant or teacher should teach the truth or the gospel to children. Presenting the gospel to children requires several age-appropriate media so that children can easily understand what is being said. One of the media used is the Puppet Stage, of course, with several methods. First, creative delivery methods to attract children's attention. Second, the method of delivery uses simple language. Third, the delivery method uses an interesting story. Fourth, the delivery method by involving children in storytelling. These four methods are quite good to use in conveying the gospel to children aged 5 - 10 years according to what has been done.

\section{REFERENCES}

[1]. Dobson, James. Masalah

Membesarkan Anak. Bandung: Kalam Hidup, 2005.

[2]. Firman Aprianto, Guntur. Implementasi Penginjilan Dan Pemuridan
Dalam Pengembangan Karakter Jujur Anak 9 - 10 Tahun 2 No. 2 (January 2020).

[3]. Gultom, Rida, Dame Taruli, and Genti Turnip. Pendidikan Agama Kristen Kepada Anak - Anak. Medan: MITRA, n.d.

[4]. Hardono, Timotius. Penginjilan. Jakarta: Bethany Bible College, 2000.

[5]. Kartika, Tabitha. "Belajar Dari Sejarah Gereja Pendidikan Kristiani Untuk Anak Melalui Sekolah Minggu” 31, no. 1 (April 2007).

[6]. Meier, Paul, Frank Minirth, Frank Wichern, and Donald Ratcleff. Pengantar Psikologi Dan Konseling Kristen. Jogjakarta: ANDI, n.d.

[7]. Moleong, Lexy. Metodologi Penelitian Kualitatif. Bandung: PT REMAJA ROSDAKARYA, 2018.

[8]. Pattinama, YA. "Dasar Alkitabiah Dalam Mengajar Anak.” Artikel. https//files.osf.io.

[9]. Richard, Lawrence. Pelayanan Kepada Anak - Anak. Bandung: Kalam Hidup, 2007.

[10]. Riniwati. "Pembinaan Guru Sekolah Minggu Untuk Mengajarkan Konsep Keselamatan Pada Anak” 4, no. 2 (July 2020).

[11]. Sapti Cahyaningrum, Eka. 
Journal Didaskalia

E-ISSN: 2621-8054

P-ISSN: 2622-1667

"Pengembangan Nilai - Nilai Karakter

Anak Usia Dini Melalui Pembiasaan Dan

Keteladanan"6, no. 2 (2017).

[12]. Simanjuntak, Cipto. "Teori Dan

Praktek Panggung Boneka.” Last modified

2018.

http://simanjuntakcipto.blogspot.com/2018

/01/teori-dan-praktek-panggung-

boneka.html) 28 Januari 2018.

[13]. Sumule, Linus. "Implementasi

Strategi Kreatifitas Dan Bervariasi Dalam

Semangat Sekolah Minggu Kelas Remaja

Dalam Menggerakan Firman Tuhan"

(2020). https//osf.io/x8cwh.

[14]. Waridah, Ernawati. Buku Pintar

$U A S B N$, n.d. 